\title{
Earthquake Hazard Zonation and Seismotectonics of the Bandar Abbas Area, Zagros, Iran
}

\author{
Saeedeh Abdolizadeh, Zahra Maleki*, Mehran Arian \\ Department of Geology, Science and Research Branch, Islamic Azad University, Tehran, Iran \\ Email: ${ }^{2}$ z.maleki@srbiau.ac.ir
}

Received 20 October 2015; accepted 27 March 2016; published 30 March 2016

Copyright (C) 2016 by authors and Scientific Research Publishing Inc.

This work is licensed under the Creative Commons Attribution International License (CC BY). http://creativecommons.org/licenses/by/4.0/

cC) (7) Open Access

\section{Abstract}

The study area (Bandar Abbas area) is located in the Zagros fold-thrust belt as part of the AlpineHimalayan orogenic belt as seismically active belt. This area is located between the Makran accretionary prism and Oman Mountains from east and the Zagros collision belt from west as transition zone. The Zagros fold-thrust belt from the viewpoint of seismicity, is very active and Iran's major earthquake-prone area. The study area has main active faults and some high magnitude earthquakes occurred in current century. Because the Bandar Abbas area has high seismic activity, the main goal of this research is prepared to earthquake hazard zonation and identify hazardous seismic zones, based on Decision Support System method for define active seismotectonic in this area. The seismotectonic study has been done in $30-100 \mathrm{~km}$ radius, for Bandar Abbas area. In this research, we used Decision Support System method by in corporate and combine essential data such as seismic data from 1900-2015, Digital Elevation Model of the study area (DEM), surface geology, seismicity parameters, soil classification and location main faults. In this research the Decision Support System (DSS) base on GIS database is used for calculate seismicity parameters. Based on the relative risk of earthquake zonation map, the Bandar Abbas area is located from the north to the East and from the South to the East, in area with high seismic risk (with Orange color). Some small regions with very high relative seismic risk have been limited to these areas with high risk. Also from north to west and from south to west "the study area" is located mainly in the area with earthquake relative risk of in areas with moderate and low relative risk of earthquakes. In the far southwestern region of the study, the small area is located in an area with high and very high seismic relative risk and this case may be due to the activity of the Mountain Front Fault (MFF) and Zagros Fore deep Fault (ZFF). Finally, the study area has been affected by active faults and it causes high vulnerability of the study area in the face of a possible occurrence of earthquakes. Based on of Seismotectonic investigations, there are existed minor faults of the Zagros fault from East to West and in the middle part. This case has been caused some parts in the study area with low and

*Corresponding author. 
moderate seismic risk to be considered in the face of possible earthquakes and seismic damages, as an area with high seismic risk.

\section{Keywords}

\section{Zagros, Bandar Abbas, Earthquake Hazard, Zonation, Active Faults}

\section{Introduction}

Iran is one of the most seismically active countries worlds and this area is located in the Alpine-Himalayan orogenic belt (Figure 1). The study area (Bandar Abbas area) is located in the Zagros fold-thrust belt as part of the Alpine-Himalayan orogenic belt as seismically active belt. The Alpine-Himalayan orogenic belt or Alpide belt have been created by closure of the Tethys Ocean and process of collision between the northward-moving African, Arabian and Indian plates with the Eurasian plate from Mesozoic-Cenozoic to recent. In addition, the Zagros fold-thrust belt as part of the Alpine-Himalayan orogenic belt as seismically active belt consequence of the Arabian-Iranian convergence [1]. In Iran country, especially in the Zagros fold-thrust belt, the earthquake events with high magnitude above 6 Richter can be caused disaster. These cases have been happened as catastrophes because of the earthquake focal depth usually located in sedimentary cover with $10 \mathrm{~km}$ thickness of the Zagros belt. The study area is located in southeastern of the Zagros fold-thrust belt (Bandar Abbas area, Hormozgan province) (Figure 1). The Bandar Abbas area as syntaxis constitutes and it is one of the main structural features within the Alpine-Himalayan orogen [2]. This area is located between the Makran accretionary prism and Oman Mountains from east and the Zagros collision belt from west as transition zone [2].

The earthquake events are eternal events on the earth planet and this event is active in the interior body of the

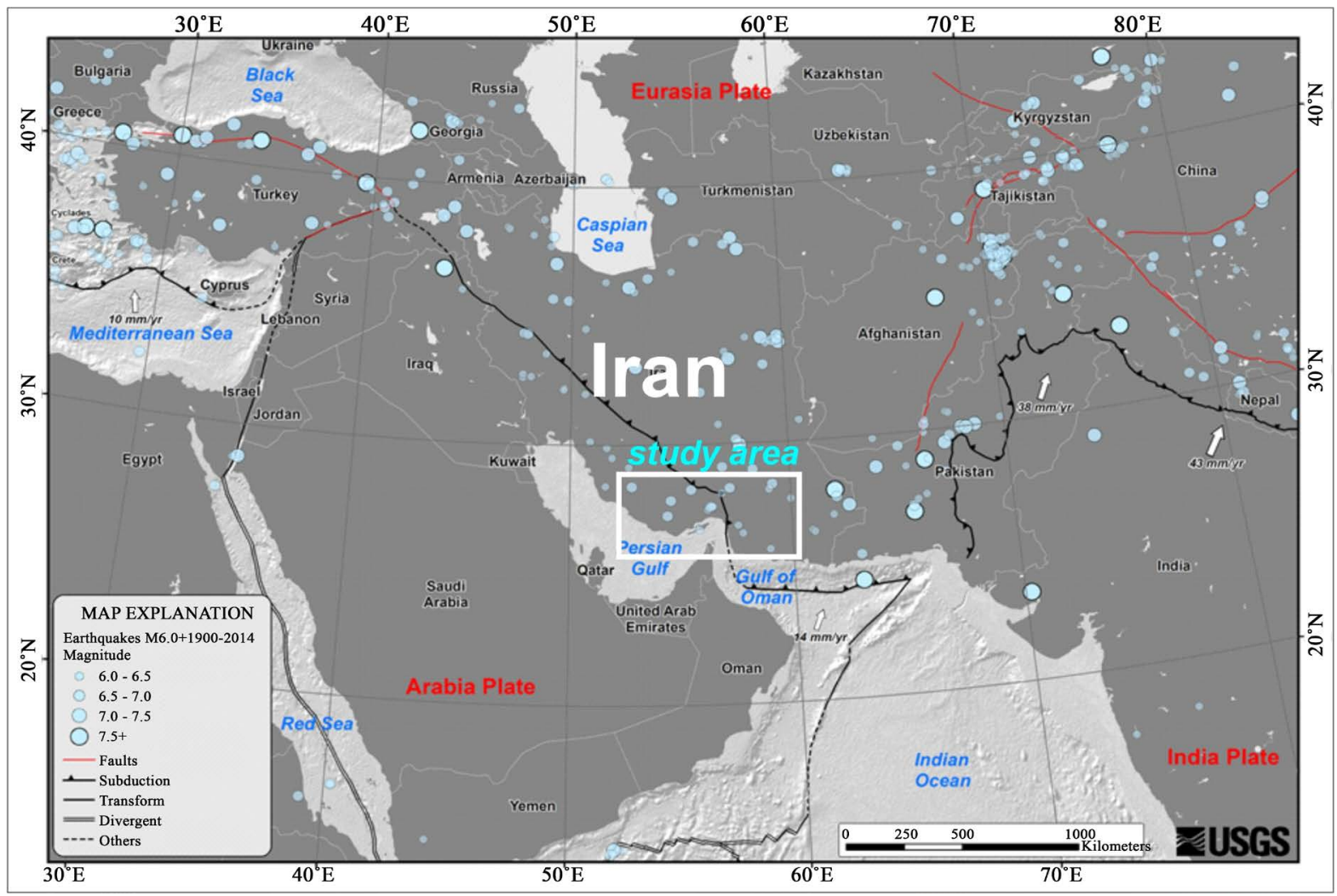

Figure 1. Map of the study area in the middle east context. In this map, the earthquake events have been shown with magnitude more than 6 richter from 1900 to 2014 (USGS). 
earth. This event usually happens in the high activity seismic areas. Sometimes, the earthquake event happens in urban or industrial area sometimes occurs in area without any inhabitants such as desert. When earthquakes have occurred in urban or industrial areas, this event is nominated disaster.

The high magnitude earthquakes events in several decades in Iran country have killed many people. This natural event should be investigated by active tectonic, seismotectonic and seismology studies. The seismicity report for an area with high seismicity history has important, especially for rehabilitation of the main constructions such as dams, powerhouses and other essential constructions in urban or industrial areas.

Seismic hazard analysis has been required an assessment of earthquake hazard parameters and the future earthquake potential in a region. Kijko and Selevoll (1992) [3] has been evaluated for each seismotectonic province of Iran, earthquake hazard parameters such as maximum expected magnitude, $M_{\max }$, seismic rate and other related parameters. In addition, geologists and seismologist with using this method, can be defined the high and very high hazardous zones that related to main active faults in any study area. Indisputable, the seismic hazardous regions have been controlled by activity of the main faults in high-risk regions. The study area has main active faults and some high magnitude earthquakes occurred in current century. Until now, many researchers have research on seismicity of Iran, Zagros and the study area (Bandar Abbas), but there have not been investigation based Decision Support System (DSS method) to deal with possible risks in the study area and so, this research has presented for the first time.

Various researchers have been done researches based on the earthquake hazard zonation. Some of these researchers have used DSS method (e.g. [3]-[7]). The Decision Support System method (DSS) is an effective and powerful method for managing earthquake risk and preparing map of the earthquake hazard zonation for urban or industrial region is GIS based Decision Support System (DSS). The system's output is very practical for prepared earthquake hazard zonation, forecasts of damage and human impacts, which will result from future earthquakes [7]. The earthquakes epicenter and active faults in the study area have been shown in the Figure 2. Be-

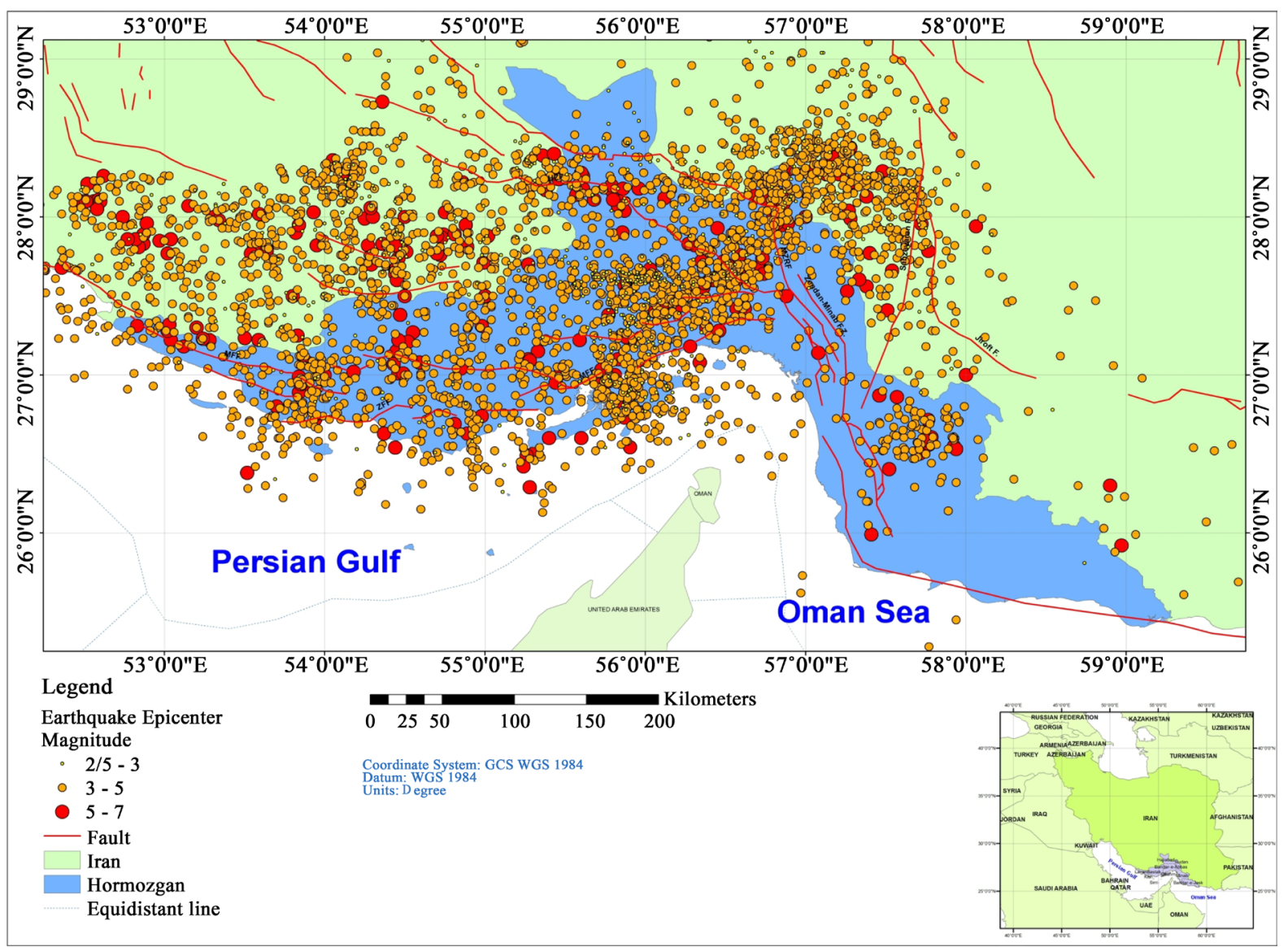

Figure 2. Map of the earthquakes epicenter and active faults in the study area and its surroundings. 
cause of the Bandar Abbas area, has high seismic activity[8]-[10], the main goal of this research is prepare to earthquake hazard zonation and identify hazardous seismic zones, based on Decision Support System method for define active seismotectonic in this area.

\section{Material and Methods}

Today, the seismic hazard zonation has been applied in many countries to prevent losses incurred from earthquakes in seismically active areas.

In addition, mapping of seismic hazards is called seismic zonation at local scales to incorporate the local site response [11]-[21]. In each seismotectonic and earthquake hazard zonation, the seismicity study has two main part seismotectonic investigation and earthquake hazard analysis the radius study around the main construction or main area have been defined with focused on geological maps scales (1:100,000 or 1:250,000 scale) and other require data. The seismotectonic study has been done in 30 - $100 \mathrm{~km}$ radius, for Bandar Abbas area. In this research, we used Decision Support System method by in corporate and combine essential data such as seismic data from 1900-2015, Digital Elevation Model of the study area (DEM), surface geology, seismicity parameters, soil classification and location main faults. In this research the Decision Support System (DSS) base on GIS database is used for calculate seismicity parameters.

Based on [22] the total stratigraphic thickness has been estimated different parts of the Zagros fold-thrust belt, for example in the central SFB about $12 \mathrm{~km}$ and in the far southeast about $10 \mathrm{~km}$. The sedimentary cover has plays a major role in this Belt and in its deformation and entitle more explanation. The simplified stratigraphic column shows in Figure 3 for southeast of the Zagros. The Proterozoic Hormuz Salt formation has important role in formation of salt plugs and diapirs across the central and southeastern SFB. This sequence of the Zagros fold-thrust belt corresponds to the mobile Hormuz evaporites. Many large Hormoz Salt Diapirs, some still active, reach the surface in the Zagros Active Folded Belt. In the Zagros belt and study area, the Paleozoic and lower Mesozoic strata have been composed of conglomerates, dolomites, massive limestones that totally nominated the "Competent Group". Upper Cretaceous to middle Miocene rocks encompasses a more mixed sequence of
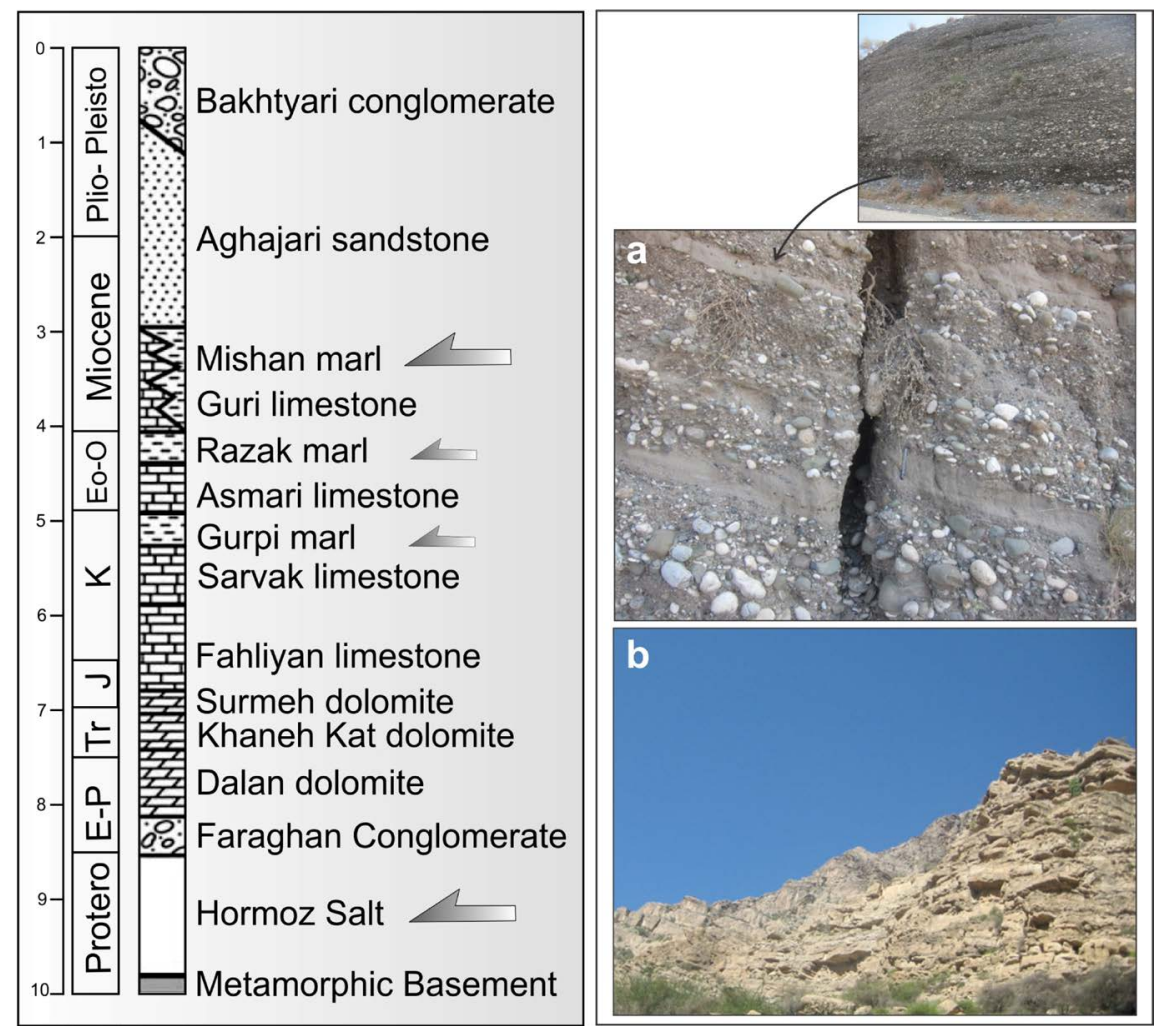

Figure 3. The simply stratigraphic column of the Bandar Abbas area (Nissen et al., 2010), images: (a) The conglomerate facies of the Bakhtiari formation in the study area, (b) The outcrop of the Aghajari formation in the kuh-e Zendan area. 
mechanically weak marls and evaporites (e.g. Gurpi, Razak and Mishan formations) intermingled with competent limestones (for example Asmari and Guri formations). In the study area from Miocene to Recent, strata composed of course, clastic sediments. This strata has been indicated the onset of regional continental shortening and uplift in the Zagros fold-thrust belt. In this belt, shallow earthquakes have been occurred within the sedimentary cover from 10 - 15 kilometer depth. This case can show deformation of the sediments and/or movements of the salt layers and their diapirism have been happened in these parts [10].

\subsection{Seismotectonic Setting and Faults}

The Zagros fold-thrust belt from the viewpoint of seismicity, is very active and Iran's major earthquake-prone area. In Iran country, more than $50 \%$ of earthquakes have been occurred in the Zagros belt and global networks have recorded these earthquakes. Most earthquakes in the Zagros have been occurred with small to medium magnitude in the sedimentary cover. The epicenter of the earthquake across the Zagros Folded Belt is distributed, but the macroseismic areas of larger earthquakes have been located along the special landforms. Large earthquakes of the Zagros have been occurred, mainly on various parts of the Zagros such as main active faults.

Earthquakes in the Zagros fold-thrust belt have been occurred in Focal depth about 4 to 18 mainly in the High Zagros Simple Folded (SFB). This event show that faulting earthquakes have been occurred in the sedimentary cover and above the Zagros basement. The largest earthquake has been happened in the Bandar Abbas area is dated back to 21 March 1977 Khurgu with 7 MS magnitude in north of the study area. It killed 152 people, injured 556 and caused destruction over an area of $550 \mathrm{~km}$. Some of the earthquakes in the Zagros belt have been happened in the Sub-sedimentary cover and the Khurgu earthquake was another "Sub-sedimentary Zagros-type earthquake". This event can considered as one of the evidence of the Zagros Active Folded Belt and show that the tectonic deformation along with surface faulting at the top of the sedimentary cover of this belt. The density of the earthquake events map in the study area has been shown in the Figure 4.

The study area is located in the Bandar-E Abbas seismotectonic province and in southeastern part of over

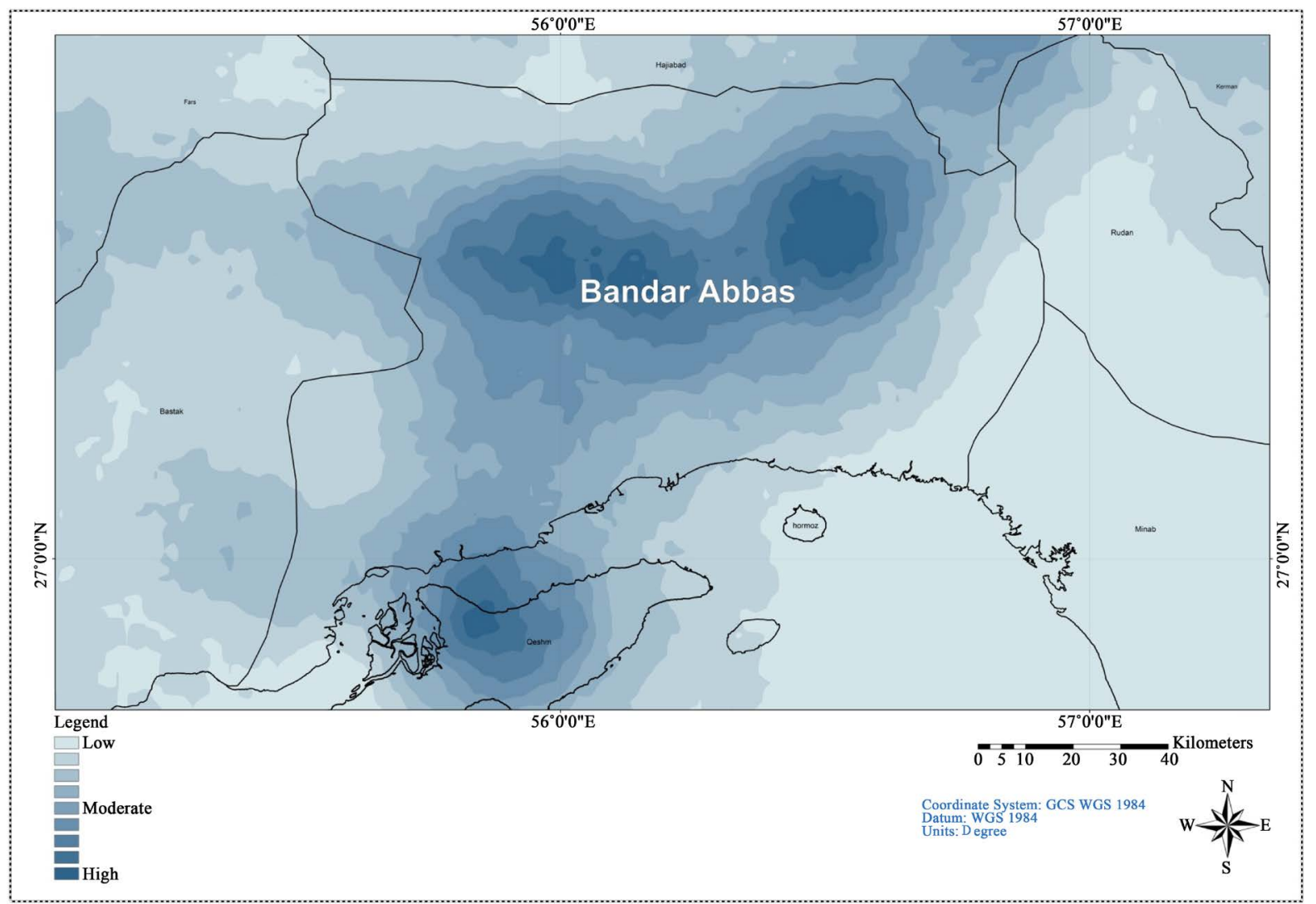

Figure 4. Density of the earthquake events map based on the earthquake epicenters in the study area. 
thrust of the Zagros simple folded belt. This area has NE-SW structural trend and earthquakes focal mechanism of the Bandar Abbas area have been shown reverse and thrust faulting mechanism such as Khurgu (Ms = 7, 1977). Main destructive earthquakes in the Bandar Abbas and adjacent area have been shown in Table 1. Based on the seismicity characteristics, the Bandar Abbas province has been highlighted with strike of the earthquake epicenters with low frequency, short repeat time and $10-20 \mathrm{Km}$ focal depth. The intensity of earthquakes is high in the middle detachment layers (ductile rocks in sedimentary covers) of the study area. The most vigorous seismic hazards have been happened in the Bandar Abbas province. Some of these events have been affected on the large cities such as Bandar Abbas, Qeshm, Bandar-e Lengeh and Hajiabad. These events have been created tsunami in southern margins, rapid uplift in northern margins and inhabitants in some lowlands and coastal areas.

Iran is one of the most seismically active countries in the world and this area is located in the Alpine-Himalayan orogenic belt. The study area (Bandar Abbas area, Hormozgan province) is located in the Zagros foldthrust belt as part of the Alpine-Himalayan orogenic belt as seismically active belt. In the Bandar Abbas area, the Zagros Mountain Front Fault and other secondary related faults joint with together in Khurgu area. Most of the main active faults in the Bandar Abbas area have been jointed to the "Minab-Zendan" fault in the East of this region (Figure 5). In addition, these faults are located in the eastern border of the Zagros belt. The active faults in the study area have been caused severe seismicity in the Hormozgan province (Table 1). The location of the active faults of the Bandar Abbas area and the epicenter of the main earthquakes are shown in Figures 4-6.

The first active main fault in the study area is the Minab-Zendan fault (MZF). This fault is located in eastern part of the Minab city with northern-southern trend (Active faults in the study area, see Figure 5). The Minab fault is a dextral strike slip fault between two plates of Arabia and Iran continental-continental as boundary in this area based on Iran geology history, the Minab fault has important role and the sedimentary facies insides of this fault have different characteristics. This fault is a structural boundary with fundamental changes in sedimentation history, paleo-geography and seismicity with NW-SE trend is located in the northern part of the study area (north of the Bandar Abbas).

The second active main fault in the study area is the Main Zagros Reverse fault. The Zagros fold-thrust belt have been bounded on the northeast by both the Main Zagros Reverse fault (MZRF) and Main Recent fault (MRF).

The main reverse fault Zagros (MZRF): along the NW-SE side (N130E) of the Marivan (western boundary of the Iran and Iraq) over 1350 kilometers to the north of Bandar Abbas to extend. Zagros main fault is characteristic of the continental margin of the Central Iran border conflict (in the northeast) and the continental margin of Afro-Arab (fold belt-thrust belt).

Other active main faults such as the High Zagros Fault (HZF), Mountain Front Fault (MFF), Zagros Foredeep Fault (ZFF), Jiroft fault (JF) and Sabzevaran fault (SF) have been affected on the study area and may be have been happened severe earthquake events in the study area. The epicenter of earthquakes has shown in Figure 5, from 1900 to 2105 year in the study area. These epicenters have been related to the location of the main active

Table 1. Main previous destructive earthquakes in the bandar Abbas and adjacent area, based on [10].

\begin{tabular}{llll}
\hline \multicolumn{1}{c}{ Event Location } & \multicolumn{1}{c}{ year } & \multicolumn{1}{c}{ Description } \\
\hline 1 & Qeshm Island earthquake & $1981-1$ (?) & A destructive earthquake \\
2 & Strait of Hormoz & $1482-1483$ & A damaging shock at Hormoz and Oman \\
3 & Hengam and Kish Islands earthquakes & $1703-4$ (?) and 1883-4 (?) & Two destructive earthquakes on these islands \\
4 & Qeshm Island earthquake & 1884 May 19-20 & Destructive earthquake in the central Part of Qeshm island \\
5 & Qeshm Island earthquake & 1897 January 11 & Destructive earthquake in Qeshm city (northeast of the island) \\
6 & Qeshm Island earthquake & 1902 July 9, (?) & Damaging earthquake at Qeshm, Bandar Abbas and Genu \\
7 & Bandar Abbas earthquake & 1905 April 25 & Damaging earthquake at Bandar Abbas, Qeshm and Hengam \\
8 & Bandar Abbas earthquake & 1907 July 4 & An earthquake felt at Bandar Abbas \\
9 & Nakhl-e-Nakhoda earthquake & 1949 April 24 & An earthquake of magnitude 6 - 6.5 which destroyed \\
10 & Sarkhun earthquake & 1975 March 7 & Nakhl-e-Nakhoda and damaged Bandar Abbas \\
11 & Genu earthquake & 1977 January 5 & A magnitude 5.8 - 6.1 earthquake damaged Sarkhun \\
\hline
\end{tabular}




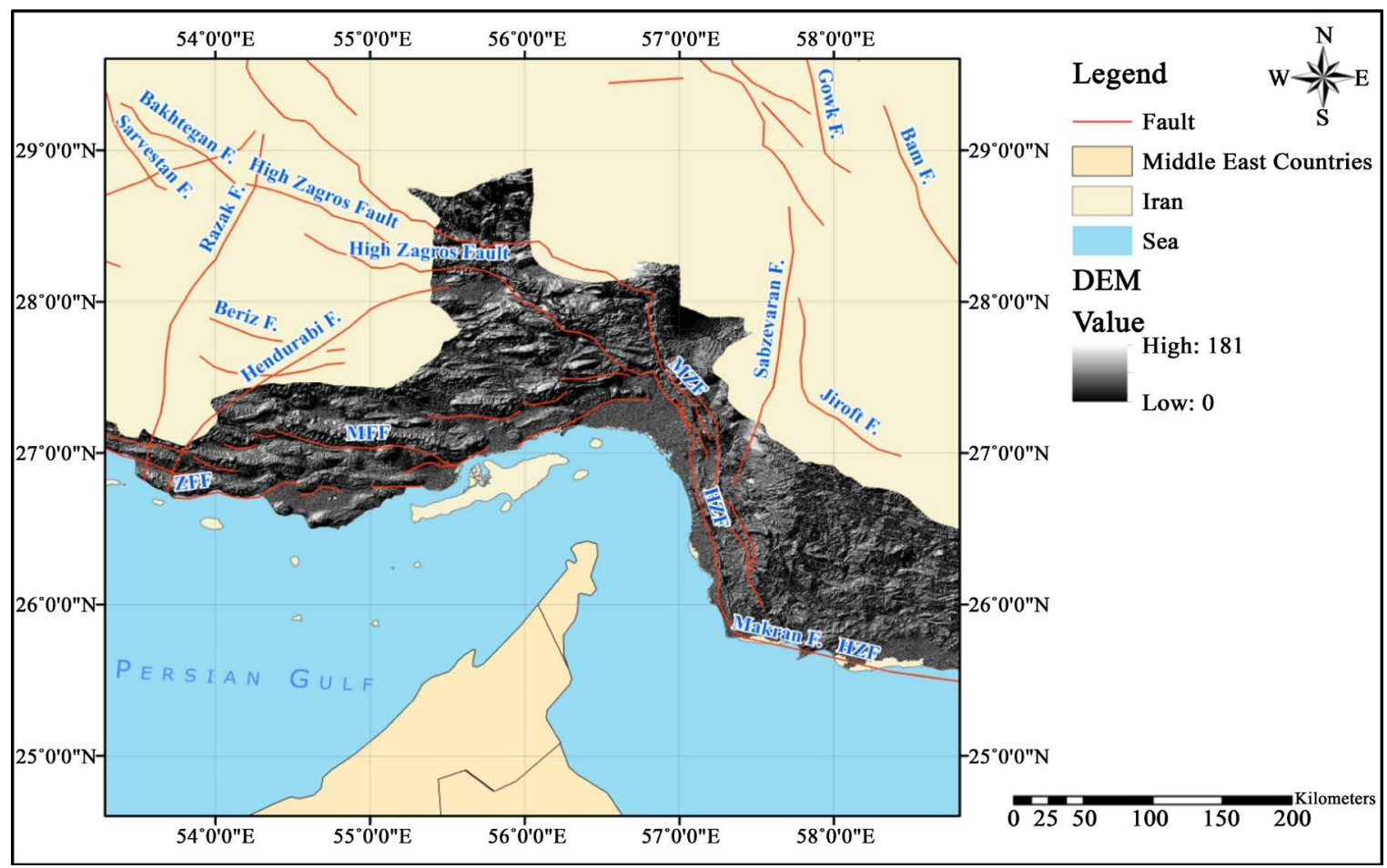

Figure 5. Active fault in the study area (Bandar Abbas, Hormozgan province).

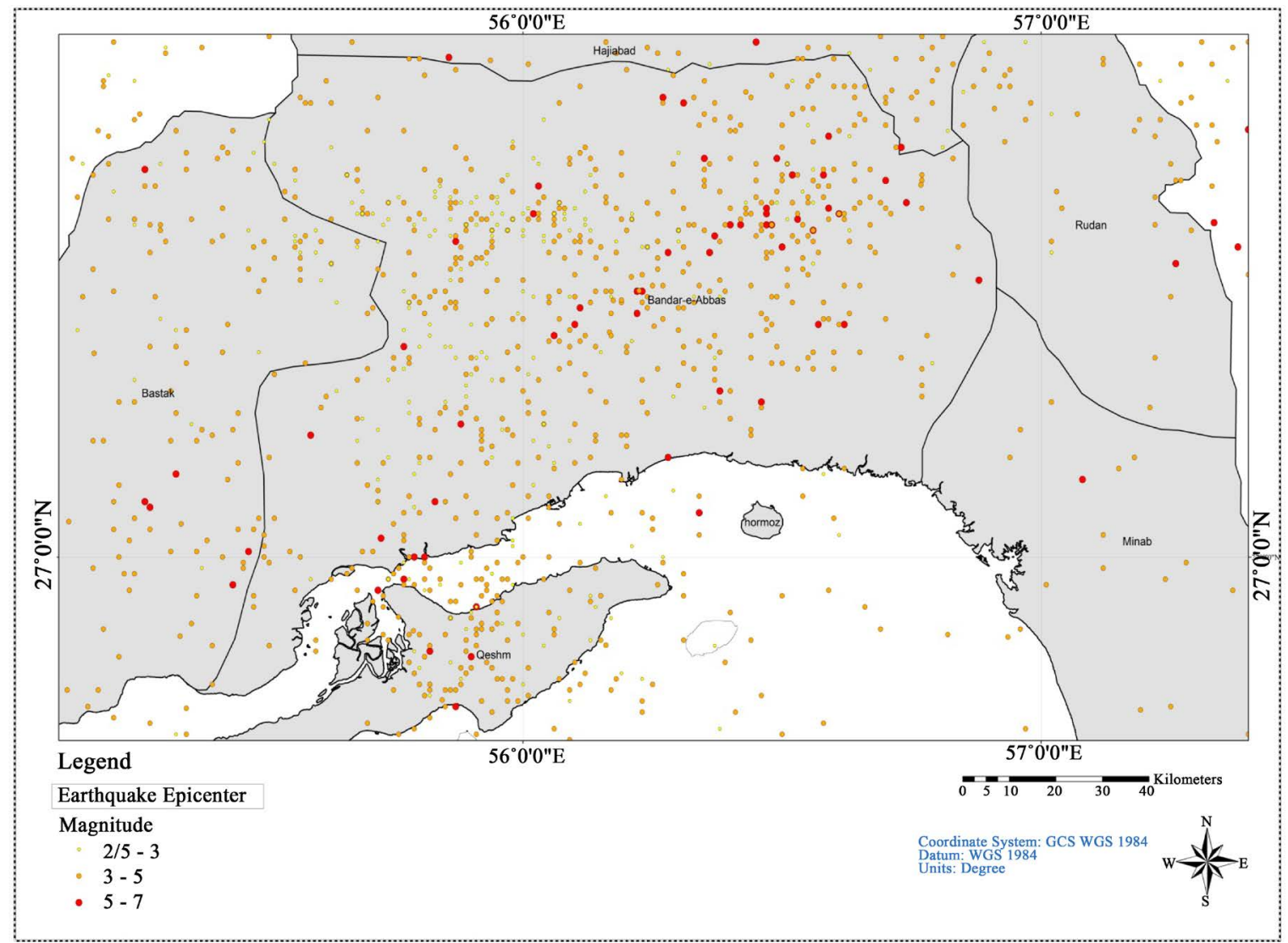

Figure 6. The epicenter of earthquakes (from 1900 to 2105 year in the study area). 
faults in the study area specially belongs to the Minab-Zendan fault (MZF), High Zagros Fault (HZF) and secondary order faults that related with Minab-Zendan fault (MZF).

\subsection{Earthquake Hazard Zonation}

The Decision Support System method for Earthquake Hazard Zonation, is a powerful GIS-base method that developed to assist geologists and geophysicist as defining earthquake hazardous zone and managing earthquake risk for an urban area [7]. The hazard map preparation is a very common use of GIS in risk assessment in natural catastrophe such as earthquake risk and other natural disasters. In developed system for identify potential hazardous seismic zones of special locations or areas; the GIS database has significant value. For applying Decision Support System method and preparing map of earthquake hazard zonation, a GIS based DSS for earthquake hazard assessment has been developed by some researchers. In this research, we used Decision Support System method by in corporate and combine essential data such as seismic data from 1900-2015, Digital Elevation Model of the study area (DEM), surface geology, seismicity parameters, soil classification and location main faults.

In this study, the Decision Support System (DSS) base on GIS database has been used for prepared earthquake hazard zonation maps for define active seismotectonic area. Some seismicity parameters such as acceleration and intensity of earthquake have been estimated for nearest active faults in the study area. In addition, for prepared DSS tree, except define seismicity parameters (e.g. Table 2), lithology has been classified in the study area. One of the main part in our GIS database is distribution of earthquakes, epicenter and focal depth of earthquakes occurred in 1900-2015 period time. Other parameters have been considered such as alluvial sediments, quality of alluvial, slope, elevation, concentrate of populations and locations of main constructions specially.

After preparing DSS tree base on GIS database, each of the prepared layers have been connected to each other by Decision tree. In this stage, all of the mentioned parameters have been considered based on GIS methods, seismicity and tectonic analysis. Also, after preparing DSS tree base on GIS database, the final score is given to

Table 2. Some of the earthquake events in the study area with $100 \mathrm{~km}$ study radius base on seismotectonic investigation.

\begin{tabular}{|c|c|c|c|c|c|}
\hline Year & Latitude & Longitude & Depth & Magnitude & Location \\
\hline 2000 & 27.56 & 56.84 & 41 & 4.2 & Hormozgan, North-West of Dehbarez \\
\hline 2000 & 27.51 & 56.83 & 0 & 4 & Hormozgan, West of Dehbarez \\
\hline 2002 & 27.64 & 56.69 & 15 & 4.8 & Hormozgan, North-West of Dehbarez \\
\hline 2002 & 27.49 & 56.62 & 33 & 4.4 & Hormozgan, North-East of Bandar-e Abbas \\
\hline 2002 & 27.64 & 56.74 & 12 & 5.3 & Hormozgan, North-West of Dehbarez \\
\hline 2002 & 27.61 & 56.62 & 33 & 3.8 & Hormozgan, North-East of Bandar-e Abbas \\
\hline 2002 & 27.6 & 56.67 & 33 & 4.1 & Hormozgan, North-West of Dehbarez \\
\hline 2002 & 27.62 & 56.71 & 15 & 4.6 & Hormozgan, North-West of Dehbarez \\
\hline 2005 & 27.34 & 56.77 & 31 & 3.1 & Hormozgan, North-West of Minab \\
\hline 2005 & 27.62 & 56.62 & 14 & 3.8 & Hormozgan, North-East of Bandar-e Abbas \\
\hline 2006 & 27.74 & 56.81 & 16 & 3 & Hormozgan, North-West of Dehbarez \\
\hline 2006 & 27.59 & 56.63 & 14 & 3 & Hormozgan, North-East of Bandar-e Abbas \\
\hline 2006 & 27.78 & 56.7 & 14 & 3.8 & Hormozgan, North-West of Dehbarez \\
\hline 2006 & 27.46 & 56.58 & 14 & 3.9 & Hormozgan, North-East of Bandar-e Abbas \\
\hline 2007 & 27.44 & 56.63 & 13 & 3.7 & Hormozgan, North-East of Bandar-e Abbas \\
\hline 2008 & 27.37 & 56.65 & 17 & 3.3 & Hormozgan, North-East of Bandar-e Abbas \\
\hline 2008 & 27.66 & 57.03 & 15 & 3.5 & Hormozgan, North-West of Dehbarez \\
\hline 2009 & 27.55 & 57.02 & 14 & 3 & Hormozgan, North-West of Dehbarez \\
\hline 2009 & 27.57 & 57.02 & 32 & 3.1 & Hormozgan, North-West of Dehbarez \\
\hline 2010 & 27.35 & 56.79 & 14 & 2.9 & Hormozgan, North-West of Minab \\
\hline 2010 & 27.77 & 56.82 & 14 & 2.9 & Hormozgan, North-West of Dehbarez \\
\hline
\end{tabular}


each branch of DSS tree.

At finally, Decision within the system has been done and the quality value of each parameter have been logged and combined in GIS system. According to this method, each created polygons have been determined the final value. In this research, the nearest active faults, seismic data, then lithology and other parameters in order have different value. At last, the earthquake hazard zonation map has been prepared base on GIS database and DSS method for seismotectonic and seismic risk analysis (Figure 7).

Based on the earthquake hazard zonation map has been prepared in the Bandar Abbas area, the main part of the area is located in an area with high seismic relative risk from North to east and from south to east. The northeast-east of the study area and a small area in the central part of the Bandar Abbas area are located in zones with very high seismic relative risk in red (Figure 7). Also, this map show that the Bandar Abbas area is located from the north to the East and from the South to the East, in area with high seismic risk (with Orange color). Some small regions with very high relative seismic risk (red color) have been limited to these areas with high risk (Orange color) (Figure 7). In addition, from north to west and from south to west of the study area are located mainly in the area with relative risk of earthquake in areas with moderate and low relative risk of earthquakes. In the far southwestern region of the study, the small area is located in an area with high and very high seismic relative risk and this case may be due to the activity of the Mountain Front Fault (MFF) and Zagros Foredeep Fault (ZFF).

In the Bandar Abbas area, most of the main active faults in this area have been jointed to the "Minab-Zendan" fault in the East of this region. These faults are located in the eastern border of the Zagros belt. The active faults in the study area have been caused severe seismicity in the Hormozgan province. The active faults with minor faults have been caused the study area as an area with high seismicity. It seems that activity of the main faults in the study area, seismicity history and location of the main active faults such as Minab-Zendan fault, Mountain Front Fault (MFF) and Zagros Foredeep Fault (ZFF) and other faults have been caused high activity based on

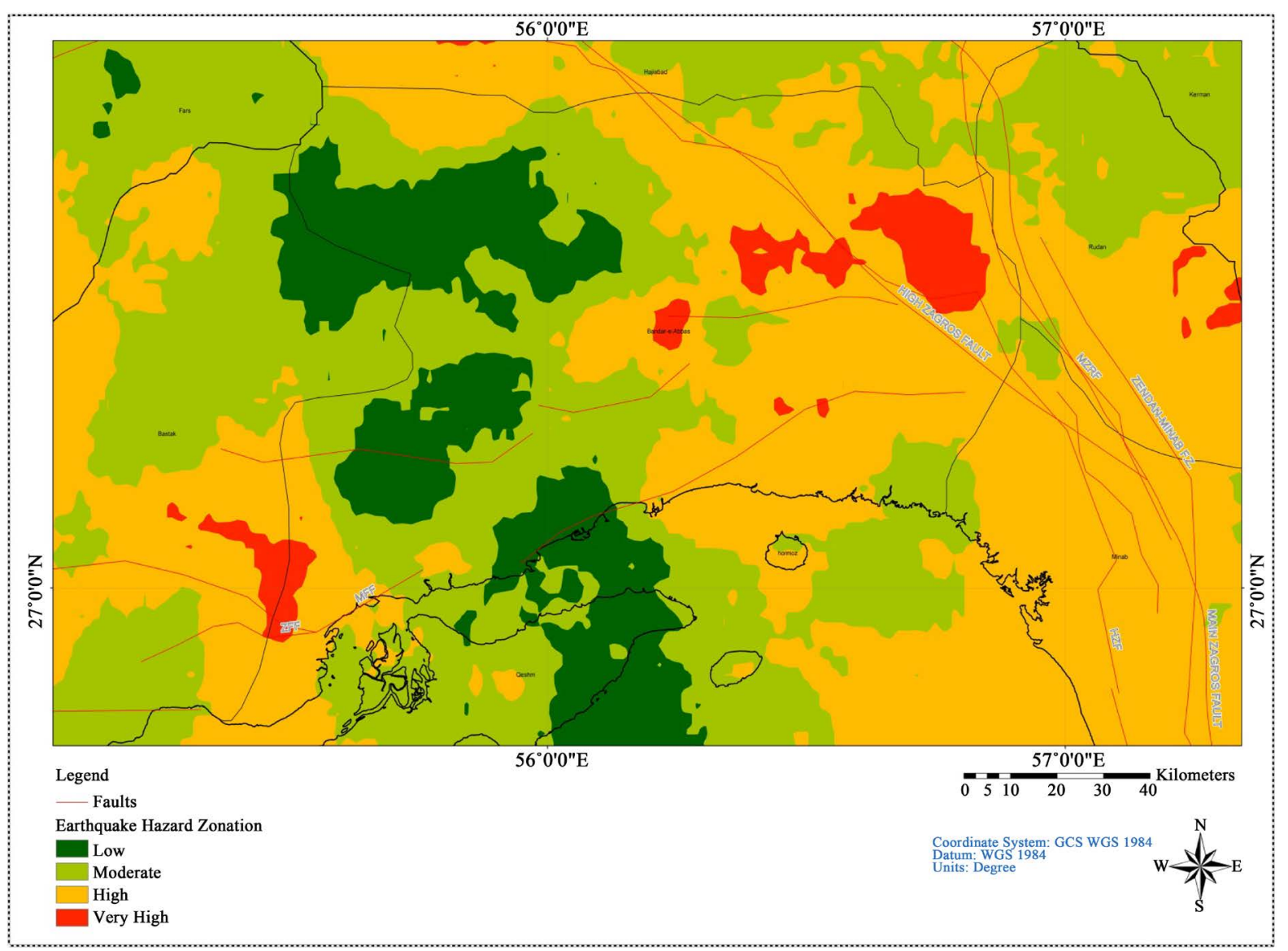

Figure 7. Earthquake hazard zonation map of the Bandar Abbas area. 
seismicity and seismotectonic. At finally, the study area has high vulnerability in the face of a possible occurrence of earthquakes.

\section{Results and Discussion}

Neotectonic regime of the study area is due to the Neogene collision between the Arabian and Iranian plates. The Zagros sedimentary rocks shows the syn-rifting facies of passive margin from the late Proterozoic to early Permian (Hormuz to Zakeen formations), post-rifting facies of passive margin from early Permian to the late Cretaceous (Faraghan to Gurpi formations) and foreland facies of syn-orogeny from the late Cretaceous to recent (Pabdeh to Bakhtyari formations) [23]-[26].

The Hormuz Salt formation with Infra-Cambrian to Cambrian age had been deposited on northeastern part of Arabian plate. The name of the Hormuz salt with up to 1000 meters thickness was taken from the Iranian Hormuz Island, in the Persian Gulf. The sedimentary succession in the study area has got about $10 \mathrm{~km}$ thickness.

Based on previous work on the salt and mud diapirism [27]-[40] and neotectonic regime in Iran [41]-[44], Zagros in south Iran is the most active zone [45]-[67]. Then, North Iran [68]-[106] and Central Iran [107]-[121] have been situated in the next orders. Based on [122], the study area is located in Bandar-e Abbas province. This province is hit by moderate to high earthquakes with low frequency, short repeat time and $10-20 \mathrm{Km}$ focal depth. The intensity of earthquakes is in middle levels in which there are ductile rocks in sedimentary covers. The most severe seismic hazards in Bandar-e Abbas province, containing large cities such as Bandar-e Abbas, Gheshm, Bandar-e Lengeh and Hajiabad, are rapid uplifting in northern margins, settlements in some lowlands and coastal areas and Tsunami in southern margins.

But based on this research, the study area has got different relative seismic risks in the larger scale that they can be classified in four levels. The areas with very high, high, moderate and low relative seismic risks have been shown by red, Orange, green and dark green colors, in respectively. The areas with very high and high relative seismic risk are closed to the Mountain Front Fault and Zagros Foredeep Fault that they have been known as active longitudinal faults.

\section{Conclusions}

Based on the relative risk of earthquake zonation map, the Bandar Abbas area is located from the north to the East and from the South to the East, in area with high seismic risk (with Orange color). Some small regions with very high relative seismic risk (red color) have been limited to these areas with high risk (Orange color) Figure. Also from North to West and from South to West "the study area" is located mainly in the area with earthquake relative risk of in areas with moderate and low relative risk of earthquakes. In the far southwestern region of the study, the small area is located in an area with high and very high seismic relative risk and this case may be due to the activity of the Mountain Front Fault (MFF) and Zagros Foredeep Fault (ZFF).

Finally, the study area has been affected by active faults and it causes high vulnerability of the study area in the face of a possible occurrence of earthquakes. Based on of seismotectonic investigations, there are existed minor faults of the Zagros fault from east to west and in the middle part. This case has caused some parts in the study area with low and moderate seismic risk to be considered in the face of possible earthquakes and seismic damages, as an area with high seismic risk.

\section{Acknowledgements}

The authors acknowledge the Department of geology, Islamic Azad University, Science and Research branch, Tehran, Iran for funded this project. In addition, we thank Vice-President for Research in Science and Research branch, Tehran.

\section{References}

[1] Storetvedt, K.M. (1990) The Tethys Sea and the Alpine-Himalayan Orogenic Belt; Mega-Elements in a New Global Tectonic System. Physics of the Earth and Planetary Interiors, 62, 141-184. http://dx.doi.org/10.1016/0031-9201(90)90198-7

[2] Molinaro, M, Guezoua, J.C, Leturmya, P, Eshraghib, S.A. and Frizon de Lamottea, D. (2004) The Origin of Changes in Structural Style across the Bandar Abbas Syntaxis, SE Zagros (Iran). Marine and Petroleum Geology, 21, 735-752. http://dx.doi.org/10.1016/j.marpetgeo.2004.04.001 
[3] Kijko, A. and Selevoll, M.A. (1992) Estimation of Earthquake Hazard Parameters from Incomplete Data Files. Part II. Incorporation of Magnitude Heterogeneity. Bulletin of the Seismological Society of America, 82, 120-134.

[4] Wang, X. and Huang, X. (2000) The Earthquake Disaster Prediction and Decision Supportsystem in Southern Area of Fujian Province in China. 12th World Conference on Earthquake Engineering, Auckland.

[5] Yaqoob, L., Ahmed Khan, N. and Subhan, F. (2014) An Overview of Existing Decision Support Systems for Disasters Management. CODEN: SINTE 8 Sci. Int. (Lahore), 26, 1765-1776.

[6] Jalayer, F., Asprone, D., Prota, A. and Manfredi, G. (2011) A Decision Support System for Post-Earthquake Reliability Assessment of Structures Subjected to Aftershocks: An Application to L’Aquila Earthquake, 2009. Bull Earthquake, 9, 997-1014. http://dx.doi.org/10.1007/s10518-010-9230-6

[7] Hang Phuong, N. (2005) Development of a Decision support system for Earthquake Risk Assessment and Loss Mitigation: The Hanoi Case study. International Journal of Geoinformatics, 1.

[8] Berberian, M. (1994) Natural Hazards and the First Earthquake Catalogue of Iran. International Institute of Earthquake Engineering and Seismology (IIEES), 1, 620.

[9] Berberian, M. and Tchalenko, S. (1976) Earthquakes of the Bandar Abbas-Hadjiabad Region (Zagros-Iran). Geological Survey of Iran, 39, 371-396.

[10] Berberian, M., Papastamatiou, D. and Qoraishi, M. (1977) Khurgu (North Bandar Abbas-IRAN) Earthquake of March 21,1977: A Preliminary Field Report and a Seismotectonic Discussion. Geological Survey of Iran, 40, 7-49.

[11] Rafieh, Z., Maleki, Z., Zare, M. and Ghaitanchi, M. (2009) Seismic Zonation and Hazard Assessment in Lorestan Province Region. Journal of Sciences, Islamic Azad University (in Persian).

[12] Maleki, Z. and Rafieh, Z. (2009) Damaging Seismic Hazard for Khorramabad area (Special Effective for Old Tissue). International Earthquake Symposium Kocaeli, 17-19 August 2009.

[13] Arian, M. and Maleki, Z. (2009) The Movement Potential Evaluation and Comparing of the Active Faults (Case Study: Major Faults in the Semnan Region). International Earthquake Symposium Kocaeli, 17-19 August 2009.

[14] Mafakherian, A. and Maleki, Z. (2005) Estimate Hazard of Seismicity Khorramabad. 1st Symposium of Earthquake, Islamic Azad University, Sari-Mazandaran (in Persian).

[15] Maleki, Z., Saeidi, A., Pourkermani, M. and Atapourfard, A. (2008) Microzonation of the Earthquake Hazard, Assessment and Comparison of Movemental Potentiality of Khorramabad's Active Faults-Iran. 2nd Sympsium on Geology, Islamic Azad University, North Tehran Branch (in Persian).

[16] Maleki, Z. and Rafieh, Z. (2008) Seismotectonic and Seismicity Hazard of Khorramabad City. 3rd Disaster Management Conference, Tehran, 18-19 February 2008. (In Persian)

[17] Rafieh, Z. and Maleki, Z. (2008) Deterministic Seismic Hazard Assessment of Ghaenat Region. 2nd Symposium on Geoscience, Islamic Azad University, North Tehran Branch. (In Persian)

[18] Maleki, Z. and Mafakherian, A. (2006) Investigation Faults and Estimate Hazard of Earthquake (Lorestan and Khorramabad City). 5th Symposium of Young Researchers Club, Geology, Islamic Azad University of Dezful Brunch. (In Persian)

[19] Mafakherian, A. and Maleki, Z. (2004) Damaging Seismicity of Khorramabad City. 1st Symposium on Geophysics, Islamic Azad University, North Tehran Branch. (In Persian)

[20] Maleki, Z. and Nejad Vakili, M. (2005) Consideration of Earthquake's Effects and Operation of Buildings Resistance against It by Focusing on Crisis Management and Recent Earthquake. 1st Disaster Management Conference, Tehran University. (In Persian)

[21] Talebian, M. and Jackson, J. (2004) A Reappraisal of Earthquake Focal Mechanisms and Active Shortening in the Zagros Mountains of Iran. Geophysical Journal International, 156, 506-526. http://dx.doi.org/10.1111/j.1365-246X.2004.02092.x

[22] Alavi, M. (2004) Regional Stratigraphy of the Zagros Fold and Thrust Belt of Iran and Its Proforeland Evolution. American Journal of Science, 304, 1-20. http://dx.doi.org/10.2475/ajs.304.1.1

[23] Arian, M. (2010) Tectonics and Sedimentation. Farazamin Press, Tehran, 307 p.

[24] Arian, M. (2013) Physiographic-Tectonic Zoning of Iran’s Sedimentary Basins. Open Journal of Geology, 3, $169-177$. http://dx.doi.org/10.4236/ojg.2013.33020

[25] Qorashi, M. and Arian, M. (2011) Tectonics of Iran. Geologic Survey of Iran, Tehran, 336 p.

[26] Arian, M. (2011) Basement Tectonics and Geology of Iran. Asar Nafis Press, Qum, 300 p.

[27] Arian, M. (2011) A Preface on Salt Diapirism of Iran. Asar Nafis Press, Qum, 309 p.

[28] Arian, M. and Noroozpour, H. (2015) The Biggest Salt-Tongue Canopy of Central Iran. Open Journal of Geology, 5, 
55-60. http://dx.doi.org/10.4236/ojg.2015.52005

[29] Asadian, F., Pourkermani, M. and Arian, M. (2007) Tectonic Geomorphology of Salt Structures in the GarmsarLasjerd Area. Geographical Research, 39, 75-84.

[30] Pourkermani, M. and Arian, M. (1997) Salt Domes of Central Iran. Journal of Humanities, 3, 29-41.

[31] Arian, M. (2012) Salt Diapirism and Tectonics. Second Edition, Asar Nafis Press, Qum, 319 p.

[32] Arian, M. and Noroozpour, H. (2015) Tectonic Geomorphology of Iran's Salt Structures. Open Journal of Geology, 5, 61-72. http://dx.doi.org/10.4236/ojg.2015.52006

[33] Asadian, F. and Arian, M. (2009) Identification of Diapiric Provinces of Central Iran through Geological and Geographical Analysis. International Journal of Agriculture Environment \& Biotechnology, 2, 3443-3451.

[34] Arian, M. (2012) Clustering of Diapiric Provinces in the Central Iran Basin. Carbonates and Evaporites, 27, 9-18. http://dx.doi.org/10.1007/s13146-011-0079-9

[35] Pourkermani, M. and Arian, M. (1998) Tectonic Geomorphology of Salt Domes in West of Zanjan Province, Iran. Geographical Research, 47, 44-53.

[36] Arian, M. and Feizi, F. (2010) The Significance of Faulting on the Surficial Spreading of Evaporitic Deposits in the Varamin-Semnan Area. Journal of Earth and Resources, 3, 1-20.

[37] Feizi, F., Arian, M. and Arian, A. (2015) Mud Diapirism on the Makran, Iran: Case Study on the Napag Mud Volcano. Open Journal of Geology, 5, 300-308. http://dx.doi.org/10.4236/ojg.2015.55027

[38] Arian, M. and Sistanipour, A. (2015) Mud Diapirism on the Gorgan, North Iran. Open Journal of Geology, 5, $442-450$. http://dx.doi.org/10.4236/ojg.2015.56041

[39] Arian, M. and Khodabakhshnezhad, A. (2015) Sedimentary Environments Can Be Changed by Geotechnology (Case Study: A Morphotectonic Idea for Design of Extensive Artificial Bay on the Iranian Plateau). International Journal of Geosciences, 6, 487-496. http://dx.doi.org/10.4236/ijg.2015.65039

[40] Arian, M. (2011) Middle East Tectonics. Asar Nafis Press, Qum, 236 p.

[41] Arian, M. (2010) Applied Seismotectonics. Farazamin Press, Tehran, 304 p.

[42] Arian, M. and Maleki, R. (2008) Neotectonics. Farazamin Research Center, Tehran, 150.

[43] Pourkermani, M. and Arian, M. (1998) Seismicity of Iran. Shahid Beheshti University Press, Tehran, 212.

[44] Pourkermani, M. and Arian, M. (1997) Seismotectonics. Dez Ab Consulting Engineers Company Press, Tehran, 270.

[45] Arian, M. and Aram, Z. (2014) Relative Tectonic Activity Classification in the Kermanshah Area, Western Iran. Solid Earth, 5, 1277-1291. http://dx.doi.org/10.5194/se-5-1277-2014

[46] Mashal, M., Pourkermani, M., Charchi, A., Almasian, M. and Arian, M. (2013) Pattern of Structural Geology Underground in Eastern of North Dezfol Embayment. Advances in Environmental Biology, 7, 260-268.

[47] Pazhoohan, M., Arian, M., Ghorashi, M. and Khosrotehrani, K. (2014) A Study of Drainage Pattern Responses to Active Tectonics in Tadvan Region, SW Iran. Geodynamics, 1, 36-41.

[48] Rahimi, N. and Arian, M. (2014) Tectonic Geomorphplogy of Kangavar-Sosangerd Region, West Iran. Advances in Environmental Biology, 8, 119-124.

[49] Arian, M. and Hashemi, A. (2008) Seismotectonic Zoning in the Zagros. Journal of Sciences, 18, 63-76.

[50] Arian, M., Ahmadnia, A., Qorashi, M. and Pourkermani, M. (2002) Structural Analysis of Mengharak Transcurrent Fault System in Zagros, Iran. Special Geo 2002 Conference Issue Geoarabia, 7, 209-210.

[51] Arian, M., Qorashi, M., Pourkermani, M. and Ahmadnia, A. (2003) Fractal Analysis of Mengharak Transcurrent Fault System in Zagros, Iran. 4th International Conference on Seismology and Earthquake Engineering, Tehran, 12-14 May 2003, 23.

[52] Arian, M., Qorashi, M. and Ahmadnia, A. (2003) Analysis of Behbahan Shear Zone. Iranian Journal of Geology, 1, $1-4$.

[53] Baharvand, S., Pourkermani, M., Ajalloian, R., Arian, M. and Nouryazdan, A.R. (2010) Seymareh Landslide and Its Role in Environmental and Geomorphologic Changes of the Pole-Dokhtar Area. Journal of the Earth, 4, 13-24.

[54] Abdideh, M., Qorashi, M., Rangzan, K. and Arian, M. (2011) Assessment of Relative Active Tectonics Using Morphometric Analysis, Case Study of Dez River (Southwestern, Iran). Geosciences, 20, 33-46.

[55] Arian, M., Qorashi, M., Pourkermani, M. and Ahmadnia, A. (2006) The Structural Significance Kareh Bas Transcurrent Fault System in the Zagros Fold and Thrust Belt. Geosciences, 15, 126-133.

[56] Arian, M. and Noroozpour, H. (2015) Seismic Activity and Fractal Geometry of Kareh Bas Fault System in Zagros, South of Iran. Open Journal of Geology, 5, 291-299. http://dx.doi.org/10.4236/ojg.2015.55026 
[57] Ehsani, J. and Arian, M. (2015) Quantitative Analysis of Relative Tectonic Activity in the Jarahi-Hendijan Basin Area, Zagros Iran. Geosciences Journal, 19, 1-15. http://dx.doi.org/10.1007/s12303-015-0016-3

[58] Omidali, M., Arian, M. and Sorbi, A. (2015) Neotectonics of Boroujerd Area, SW Iran by Index of Active Tectonics. Open Journal of Geology, 5, 309-324. http://dx.doi.org/10.4236/ojg.2015.55028

[59] Chegini, A., Sorbi, A. and Arian, M. (2015) Active Tectonics of Hamedan Area, West Iran. International Journal of Geography and Geology, 4, 109-128.

[60] Maleki, Z., Arian, M., Solgi, A. and Ganjavian, M.A. (2014) The Elements of Fold Style Analysis in the Khaftar Anticline, Zagros, Iran. Open Journal of Geology, 4, 79-92. http://dx.doi.org/10.4236/ojg.2014.43008

[61] Maleki, Z., Arian, M. and Solgi, A. (2014) Structural Style and Hydrocarbon Trap of the Karbasi Anticline, Interior Fars Region, Zagros, Iran. Solid Earth Discussions, 6, 2143-2167. http://dx.doi.org/10.5194/sed-6-2143-2014

[62] Ehsani, J., Arian, M. and Ghorashi, M. (2015) Geomorphic Signatures of Active Tectonics in the Jarahi-Hendijan Drainage Basin in the South West Iran. Geosciences, 24, 211-218.

[63] Khodabakhshnezhad, A., Pourkermani, M., Arian, M., Matkan, A.A. and Charchi, A. (2015) Active Tectonics of Great Karoun River Basin. Geosciences, 24, 13-28.

[64] Maleki, Z., Arian, M., Solgi, A. and Ganjavian, M.A. (2015) Elements of Fold Style Analysis in the Karbasi Anticline, Interior Fars Region, Zagros. Geosciences, 24, 293-302.

[65] Baratpour, F., Arian, M. and Solgi, A. (2015) Geometric Analysis of Tukak and Kamarun Anticlines on Izeh Zone, Zagros. Geosciences, 24, 191-200.

[66] Gholamhosein Fard, N., Sorbi, A. and Arian, M. (2015) Active Tectonics of Kangavar Area, West Iran. Open Journal of Geology, 5, 422-441. http://dx.doi.org/10.4236/ojg.2015.56040

[67] Maleki, Z., Arian, M. and Solgi, A. (2015) Folding Pattern in the Fars Province, Zagros Folded Belt: Case Study on the Karbasi and Khaftar Anticlines, Interior Fars, Iran. Solid Earth Discussions, 7, 2347-2379. http://dx.doi.org/10.5194/sed-7-2347-2015

[68] Alladin, Y., Talebian, M., Arian, M. and Ahmadi, M.M. (2015) Geotechnical Investigation and Seismic Zonation of Alluvial Deposits in Western Tehran. Geosciences, 24, 333-342.

[69] Taherkhani, B., Nazari, H., Pourkermani, M. and Arian, M. (2015) Geometry and Recent Kinematics of the North Qazvin Fault: Morphotectonic Approach. Geosciences, 24, 29-38.

[70] Haj Manuchehri, M., Arian, M., Ghorashi, M., Solgi, A. and Sorbi, A. (2015) Geomorphic Signatures of Active Tectonics in the Chalus Drainage Basin in the Alborz, Iran. Geosciences, 24, 273-280.

[71] Noroozpour, H., Arian, M. and Sorbi, A. (2015) Fault Movement Potentials in the Tehran-Semnan Region (North Iran). Open Journal of Geology, 5, 281-290. http://dx.doi.org/10.4236/ojg.2015.55025

[72] Arian, M., Maleki, Z. and Noroozpour, H. (2011) Cenozoic Diastrophism and Deformational Events in the East Central Alborz. Journal of Basic and Applied Scientific Research, 1, 2394-2400.

[73] Feizi, F., Arian, A. and Rahmani, R. (2007) Seismotectonic Zoning in the Eastern Part of the Central Alborz. Journal of Sciences, 17, 151-164.

[74] Khavari, R., Arian, M. and Ghorashi, M. (2009) Neotectonics of the South Central Alborz Drainage Basin, in NW Tehran, N Iran. Journal of Applied Sciences, 9, 4115-4126. http://dx.doi.org/10.3923/jas.2009.4115.4126

[75] Arian, M. and Bagha, N. (2012) Active Tectonics of Tehran Area, Iran. Journal of Basic and Applied Scientific Research, 2, 3805-3819.

[76] Bagha, N., Arian, M., Ghorashi, M., Pourkermani, M., El Hamdouni, R. and Solgi, A. (2014) Evaluation of Relative Tectonic Activity in the Tehran Basin, Central Alborz, Northern Iran. Geomorphology, 213, 66-87. http://dx.doi.org/10.1016/j.geomorph.2013.12.041

[77] Arian, M. and Feizi, F. (2005) Application of Geomorphic Indices to the Assessment of Relative Tectonic Activity Levels in the Alborz-Central Iran Border Zone. Journal of Sciences, 15, 378-403.

[78] Arian, M., Bagha, N., Khavari, R. and Noroozpour, H. (2012) Seismic Sources and Neo-Tectonics of Tehran Area (North Iran). Indian Journal of Science and Technology, 5, 2379-2383.

[79] Moghimi, H., Arian, M. and Sorbi, A. (2015) Fault Movement Potential of Marzanabad Area, North Alborz, Iran. Open Journal of Geology, 5, 126-135. http://dx.doi.org/10.4236/ojg.2015.53012

[80] Arian, M. and Pourkermani, M. (2004) Tectonic Elements of South Flank in the East-Central Alborz Mountain. Journal of Sciences, 4, 359-368.

[81] Arian, M. and Qorashi, M. (2006) The Movement Potential Evaluation of the Major Quaternary Faults in Alborz-Central Iran Border Zone, from the East of Tehran to the East of Semnan. Geosciences, 15, 184-188.

[82] Poroohan, N., Pourkermani, M. and Arian, M. (2013) An Assessment of Relationship in F-Parameter and Paleostress 
Fields in Heterogeneous Lithologies: Roudbar Area (Northwest of Iran). Australian Journal of Basic \& Applied Sciences, 7, 933-942.

[83] Poroohan, N., Poukermani, M. and Arian, M. (2009) An Assessment on Correlations of Seismotectonic Parameters Preceding and Following Roudbar-Manjil Earthquake (Gilan, North of Iran). Australian Journal of Basic \& Applied Sciences, 3, 2643-2652.

[84] Farrokhnia, A.R., Pirasteh, S., Pourkermani, M. and Arian, M. (2011) Geo-Information Technology for Mass Wasting Hazard Zonation: Central-West Alborz-Iran. Disaster Advances, 4, 24-33.

[85] Khavari, R., Ghorashi, M. and Arian, M. (2009) Assessment of Relative Active Tectonics, South Central Alborz (North Iran). EGU General Assembly Conference Abstracts, 11, 1137.

[86] Sorbi, A., Arian, M. and Pourkermani, M. (2009) The Movement Potential Evaluation of the Major Quaternary Faults in Tehran Quadrangle. Journal of the Earth, 19, 176-182.

[87] Feizi, F. and Arian, M. (2006) The Classification of Thrust Fronts in the Alborz-Central Iran Border Zone from the East of Varamin to the East of Semnan. Journal of Sciences, 16, 75-87.

[88] Vaseghi, H., Maleki, Z. and Arian, M. (2016) Structural Style in the Zagros Fold-Thrust Belt: The Gavbast Anticline, Coastal Fars. Open Journal of Geology, 6, 109-116.

[89] Arian, M. and Pourkermani, M. (2004) Structural Significance of North Semnan and Attary Faults in Alborz-Central Iran Border Zone. Journal of Science, 14, 4551-4569.

[90] Arian, M. and Pourkermani, M. (2005) Cenozoic Diastrophism and Deformational Events in the Southern Flank of Central-East Alborz. Journal of Faculty Earth Sciences, 10, 43-51.

[91] Arian, M., Pourkermani, M., Qorashi, M. and Ghasemi, M.R. (2003) North Semnan Fault System and Its Role on Basin Division. 8th Symposium of Geological Society of Iran, Shahrood University of Technology, 4-6 September 2003, 11-17.

[92] Pourkermani, M. and Arian, M. (2001) Structural Geomorphology of Northeastern Kurdistan. Journal of Humanities, 7, 37-48.

[93] Mardani, Z., Ghorashi, M. and Arian, M. (2011) Geomorphic Signatures of Active Tectonics in the Talaghan Rud, ShahRud and Sefidrud Drainage Basins in Central Alborz, N Iran. Geosciences, 20, 159-166.

[94] Sorbi, A., Arian, M. and Pourkermani, M. (2011) The Application of Geomorphic Indices to the Assessment of Relative Tectonic Activity Levels in Tehran Quadrangle. Journal of the Earth, 6, 1-9.

[95] Khavari, R., Ghorashi, M., Arian, M. and Khosrotehrani, K. (2010) Geomorphic Signatures of Active Tectonics in the Karaj Drainage Basin in South Central Alborz, N Iran. Geosciences, 19, 67-74.

[96] Javadi Mousavi, E. and Arian, M. (2015) Tectonic Geomorphology of Atrak River, NE Iran. Open Journal of Geology, 5, 106-114. http://dx.doi.org/10.4236/ojg.2015.53010

[97] Nouri, R., Jafari, M.R., Arian, M., Feizi, F. and Afzal, P. (2013) Correlation between Cu Mineralization and Major Faults Using Multifractal Modelling in the Tarom Area (NW Iran). Geologica Carpathica, 64, 409-416. http://dx.doi.org/10.2478/geoca-2013-0028

[98] Nouri, R., Jafari, M.R., Arian, M., Feizi, F. and Afzal, P. (2013) Prospection for Copper Mineralization with Contribution of Remote Sensing, Geochemical and Mineralographical Data in Abhar 1:100,000 Sheet, NW Iran. Archives of Mining Sciences, 58, 1071-1084. http://dx.doi.org/10.2478/amsc-2013-0074

[99] Nouri, R., Afzal, P., Arian, M., Jafari, M. and Feizi, F. (2013) Reconnaissance of Copper and Gold Mineralization Using Analytical Hierarchy Process in the Rudbar 1: 100,000 Map Sheet, Northwest Iran. Journal of Mining and Metallurgy, 49, 9-19.

[100] Farrokhnia, A.R., Pirasteh, S., Pradhan, B., Pourkermani, M. and Arian, M. (2011) A Recent Scenario of Mass Wasting and Its Impact on the Transportation in Alborz Mountains, Iran Using Geo-Information Technology. Arabian Journal of Geosciences, 4, 1337-1349. http://dx.doi.org/10.1007/s12517-010-0238-7

[101] Arian, M. and Nouri, R. (2015) Lineament Tectonics and Mineralization in Tarom Area, North Iran. Open Journal of Geology, 5, 115-124. http://dx.doi.org/10.4236/ojg.2015.53011

[102] Feizi, F. and Arian, M. (2011) The Role of Structural Controllers in Geneses of Copper Deposits in 1:50000 Map of Saiin Qaleh. Journal of Sciences, 21, 1-10.

[103] Bahiraee, S., Arian, M., Qorashi, M. and Solgi, M. (2015) The Movement Potential Evaluation of the Mosha Fault (the West of Firoozkuh to the Shahrestanak). Geosciences, 24, 123-126.

[104] Bagha, N., Ghorashi, M., Arian, M., Pourkermani, M. and Solgi, A. (2015) Neotectonic Analysis of Mosha-North Tehran Fault Zone, Based on Morphotectonic Features, Central Alborz, Northern Iran. Geosciences, 24, 41-52.

[105] Mosavi, E. and Arian, M. (2015) Neotectonics of Kashaf Rud River, NE Iran by Modified Index of Active Tectonics (MIAT). International Journal of Geosciences, 6, 776-794. http://dx.doi.org/10.4236/ijg.2015.67063 
[106] Nouri, R. and Arian, M. (2015) Structural Control on the Distribution of Hydrothermal Alteration Zones and Mineralization in Dastjerdeh Area Based on Remote Sensing Data, NW Iran. Bulletin of the Georgian National Academy of Sciences, 9, 79-86.

[107] Sistanipour, A. and Arian, M. (2015) Geometric Analysis of Davaran Fault System, Central Iran. Open Journal of Geology, 5, 458-469. http://dx.doi.org/10.4236/ojg.2015.56043

[108] Nazemi, M., Ghorashi, M., Ghassemi, M.R. and Arian, M. (2015) Morphotectonics Features of Alluvial Fans Associated with Active Tectonics (Shotori Mountains, East of Tabas-Central Iran). Geosciences, 24, 91-100.

[109] Alizadeh, H. and Arian, M. (2015) Rule of Structural Factors in Formation of Porphyry Copper Deposits in South Western Part of Kerman Area, Iran. Open Journal of Geology, 5, 489-498. http://dx.doi.org/10.4236/ojg.2015.57045

[110] Javadi Mosavi, E. and Arian, M. (2015) Neotectonics of Tabas Area, Central Iran by Index of Active Tectonics (IAT). Open Journal of Geology, 5, 209-223. http://dx.doi.org/10.4236/ojg.2015.54019

[111] Jamalian Daryani, N., Arian, M. and Rashidnezhad Omran, N. (2015) Tectonics and Mineralization of Copper in the Ardestan-Kahang Area, Central Iran by Remote Sensing. Open Journal of Geology, 5, 188-196. http://dx.doi.org/10.4236/ojg.2015.54017

[112] Arian, M. and Pourkermani, M. (2001) Rivers Morphology and Active Tectonic (Reviewing the Current Status of Ghezel Ozon River in the Province of Zanjan). 5th Conference of Geological Society of Iran, Tehran, 28-30 August 2001, 556.

[113] Eshghi, Z., Arian, M. and Pourkermani, M. (2012) Structural Investigation on the Lak Mining Area (Bueen Zahra) Based on Remote Sensing, Used for Its Mineralization. Journal of the Earth, 6, 145-155.

[114] Arian, M., Toudeshki, V.H. and Noroozpour, H. (2011) Active Tectonics of Qezel Ozan River Basin, NW Iran. Journal of Applied Environmental and Biological Sciences, 1, 291-295.

[115] Alizadeh, H., Arian, M., Lotfi, M., Ghorashi, M. and Ghorbani, M. (2015) Determination of Porphyry Copper Deposit Locations Using Photo Lineament Factor in Northern Parts of the Dehaj-Sardoiyeh Belt. Geosciences, 24, $247-252$.

[116] Housini Toudeshki, V., Pourkermani, M., Arian, M. and Khosrotehrani, K.H. (2011) Influence of Structures on the Ghezel Ozan River. Geosciences, 21, 55-60.

[117] Housini Toudeshki, V. and Arian, M. (2011) Morphotectonic Analysis in the Ghezel Ozan River Basin, NW Iran. Journal of Geography and Geology, 3, 258-260. http://dx.doi.org/10.5539/jgg.v3n1p258

[118] Arian, M., Pourkermani, M., Sistanipour, A. and Noroozpour, H. (2011) Kinematic Significance of Fold- and FaultRelated Fracture Systems in the Rafsanjan's Northeast Highlands (Central Iran). Journal of Basic and Applied Scientific Research, 1, 3398-3406.

[119] Arian, M., Pourkermani, M., Sistanipour, A. and Noroozpour, H. (2011) Seismicity and Fault Segmentation of Bafq-Baghin Fault System (Central Iran). Journal of Applied Environmental and Biological Sciences, 1, 382-396.

[120] Javadi Mosavi, E., Arian, M., Ghorashi, M. and Nazemi, M. (2012) Measurments of Geomorphic Indices in Tabas Area. Journal of the Earth, 7, 213-225.

[121] Arian, M. (2010) Earthquake-Fault Hazard Investigations in the Kerman Quadrangle. Journal of Sciences, 19, $176-182$.

[122] Arian, M. (2015) Seismotectonic-Geologic Hazards Zoning of Iran. Earth Sciences Research Journal, 19, 7-13. http://dx.doi.org/10.15446/esrj.v19n1.40664 